the germination of rye-grass seed is below average is common knowledge, and all available evidence indicates that this reduced germination is due to the incidence of blind seed disease. The disease must, therefore, be regarded as of long standing, attention having been focused on it in recent years due to the susceptibility to attack shown by indigenous strains of rye-grass.

It is not unlikely that the natural susceptibility of such strains to the disease coupled with their shyness in seed production has operated as a primary factor in bringing about their general elimination from commerce. The continuous harvesting of the seed without sufficient reference to the strain of the grass would operate automatically in the same direction, and the forage value of the crop which, after all, is of the greatest importance, may have suffered in consequence.

Plant Disease Division,

Ministry of Agriculture,

The Queen's University, Belfast. Jan. 18.

${ }^{1}$ Muskett, A. E., and Calvert, E. L., NAture, 146, 200 (1940).

${ }^{2}$ Neill, J. C., and Hyde, E. O.C., N.Z. J. Sci. and Tech., 20, 281A (1939)

s Neill, J. C., and Hyde, E. O. C., N.Z. J. Sei. and Tech., 24, 65A (1942)

4 Wilson, M., Noble, M., and Gray, E. G., NATURE, 146, 492 (1940).

\section{White Plumage of Sea-Birds}

IT is often considered that the white plumage of gulls, terns, gannets, etc., in temperate climates is in contradiction to the principle of protective and adaptive coloration, and survives only because these birds are relatively safe from attack and able to protect themselves. Thus Cott" remarks that "in any normal surroundings" they are "positively conspicuous" but considers, that their strength and pugnacity protect them.

As is now well known, aircraft of Coastal Command on anti-submarine patrol are painted white on their undersides. This treatment was devised by Merton of their Operational Research Section on theoretical grounds, to render them less visible to submarines. Since any natural object is less bright than the sky, it will appear dark when seen from below against the sky, though at long distances the contrast will be slight, due to the great amount of scattered airlight between observer and object. Merton showed that a white object will have a smaller contrast against the sky than a darker one, even at ranges of several miles, and that white paint should therefore decrease the range at which the submarine look-outs spotted the aircraft and gave warning to submerge. Surely the same end may have been achieved, by natural selection, in the white coloration of the undersides of many sea-birds which depend for their food on spotting and catching fish very near the surface. If the bird is white its contrast against the sky will be smaller and the fish will be less likely to see it in time to dive beyond the bird's reach. As the visual acuity of fish is much poorer than that of man the ranges involved are short and the reduction of contrast by scattered light negligible; hence the benefit of white coloration will be greater than in the case of aircraft.

The majority of sea-birds (apart from shore-feeders) which have dark plumage, like cormorants and guille- mots, are diving birds which swim at considerable depths; it should therefore matter little to them whether fish dive deeper at their approach-perhaps indeed they see fish from below in silhouette, in which case their own dark coloration would be an advantage.

Psychological Laboratory,

K. J. W. Cratk. Cambridge.

Nov. 24.

1 Cott, H. B., “Adaptive Colouration in Animals" (Methuen 1940).

\section{Analysis of Barley from King Tuthankhamen's Tomb}

Through the kindness of Mr. J. Philp, chief botanist of the Ministry of Agriculture, Egypt, we recently obtained a small sample of ancient Egyptian barley from the Museum of Antiquities, Cairo, which came originally from the tomb of Tuthankhamen (c. 1350 B.o.). The barley is extensively carbonized, but its structure is sensibly undamaged and the germ, for example, with its scutellum and embryo components, is still intact. It has, however, apparently lost a considerable amount of weight and its density is only about two thirds that of fresh English barley.

No vitamin $B_{1}$ could be detected in the grain, even in the dissected scutellum. On the other hand, the contents of riboflavin and nicotinic acid, as determined by microbiological assay, were found to be $0.85 \mu \mathrm{gm}$. and $28 \mu \mathrm{gm}$./gm. respectively: the corresponding values for fresh barley average $2.5 \mu \mathrm{gm}$. and $90 \mu \mathrm{gm} . / \mathrm{gm}$.

The total phosphorus in the barley was found to be $414 \mathrm{mgm}$. per $100 \mathrm{gm}$. and the phytate phosphorus $0.4 \mathrm{mgm} . / 100 \mathrm{gm}$. Average values for fresh barley are 370 and $249 \mathrm{mgm}$./100 gm. respectively. There has, therefore, been practically complete hydrolysis of the phytic acid originally present in the grain, but no trace of an active phytase can now be found. Likewise the grain gives no reaction for phosphatase.

It is surprising to find that a molecule so complex as riboflavin could survive for such a long period. Part of the explanation is to be found in the very low relative humidity in the tomb, while we have also observed that the barley has increased in acidity, a 1 per cent suspension giving a $p H$ value of $4 \cdot 1$ as against $6 \cdot 25$ for fresh barley. We have no information on how the barley was stored; but it is possible that its preservation was helped by an oxygen-free atmosphere created by its own respiration and the oxygen uptake of other products stored with it.

Although the germ was intact, it was found to contain a number of well-defined crystals, and these are being examined by our colleague, Dr. Hinton, in an attempt to establish their chemical identity. It will also be of interest to know if the crystals are composed of a product with a very small velocity of crystallization.

E. C. Barton-Wright.

R. G. Bоoтн.

W. J. S. Pringle.

Cereals Research Station,

Ministry of Food, St. Albans.

Feb. 10. 